ISSN Print : 1411 - 951 X, ISSN Online : 2503-1716

Jurnal Ergonomi Indonesia

(The Indonesian Journal of Ergonomic)

Vol.4, No.2 : 1 Juli-Desember 2018

\title{
PERBAIKAN STASIUN KERJA DAN WILLIAM'S FLEXION EXERCISE DAPAT MENURUNKAN BEBAN KERJA, KELUHAN MUSKULOSKELETAL, DAN MENINGKATKAN PRODUKTIVITAS KERJA PADA PEKERJA PENYORTIRAN BUAH TOMAT DI DESA SEMANDING
}

\author{
${ }^{1}$ Herta Meisatama, ${ }^{2}$ Nyoman Adiputra, ${ }^{3}$ I.D.P Sutjana, ${ }^{4}$ I Nyoman Sucipta, ${ }^{5}$ I Nyoman \\ Sutarja, ${ }^{6}$ Susy Purnawati \\ ${ }^{1}$ Mahasiswa Program Studi Magister Ergonomi Fisiologi Kerja Universitas Udayana \\ ${ }^{2}$ Staff Dosen Program Studi Magister Ergonomi Fisiologi Universitas Udayana \\ ${ }^{3}$ Staff Dosen Program Studi Kesehatan dan Keselamatan Kerja Institut Ilmu \\ Kesehatan Medika Persada Bali \\ ${ }^{4}$ Staff Dosen Program Studi Teknik Pertanian Universitas Udayana \\ ${ }^{5}$ Staff Dosen Program Studi Teknik Sipil Universitas Udayana \\ ${ }^{6}$ Staff Dosen Departemen Ilmu Faal Universitas Udayana
}

hertameisatama@gmail.com

\begin{abstract}
ABSTRAK
Penyortiran merupakan proses pemilihan buah dengan kategori buah yang baik atau layak jual dan buah yang busuk atau buah yang rusak. Proses penyortiran dilakukan dengan posisi kerja duduk jongkok dilantai. Perubahan sikap duduk tersebut akan berubah dengan waktu yang lama tepatnya ketika otot terasa tidak nyaman. Peneliti memberikan intervensi berupa pemberian william's flexion exercise dan perbaikan stasiun kerja berupa penambahan meja kerja dan kursi untuk mengurangi terjadinya sikap kerja yang tidak alamiah. Penelitian ini merupakan penelitian eksperimental, dengan rancangan sama subjek. Periode (I) subjek diberi perlakuan dengan kondisi kerja konvensional. Periode (II) subjek diberi perlakuan dengan intervensi berupa pemberian william's flexion exercise dan perbaikan stasiun kerja. Perbaikan stasiun kerja berupa penambahan meja kerja dan kursi. Diantara kedua tahap tersebut, diberikan washing out period dan adaptasi. Keluhan muskuloskeletal diukur dengan kuesioner Nordic Body Map pada 5 skala likert, beban kerja dengan menghitung denyut nadi kerja pekerja dan produktivitas kerja berdasarkan perbandingan output dan input. Normalitas data diuji dengan ShapiroWilk, uji t-paired untuk menguji perbedaan kemaknaan variabel keluhan muskuloskeletal, beban kerja dan produktivitas kerja. Hasil penelitian ini menunjukkan bahwa Perbaikan stasiun kerja dan Pemberian william's flexion exercise berpengaruh secara signifikan $(p<0,05)$. Terjadi penurunan muskuloskeletal sebesar $37 \%$, penurunan beban kerja sebesar $13 \%$, dan peningkatan produktivitas sebesar 23\%. Dapat disimpulkan bahwa pemberian william's flexion exercise dan perbaikan stasiun kerja dapat menurunkan keluhan keluhan muskuloskeletal, beban kerja dan meningkatkan produktivitas kerja pada pekerja penyortir buah tomat. Sehingga disarankan untuk diterapkan pada pemilik usaha, untuk meminimalkan keluhan akibat proses kerja menyortir.
\end{abstract}

Kata Kunci : William's Flexion Exercise, Perbaikan Stasiun Kerja, Keluhan Muskuloskeletal, Beban Kerja, Produktivitas 


\section{ABSTRACT \\ IMPROVEMENT OF WORK STATION AND WILLIAM'S FLEXION EXERCISE REDUCE WORKLOAD, MUSCULOSKELETAL COMPLAINT, AND INCREASE WORK PRODUCTIVITY ON WORKERS OF TOMATO FRUITS IN SEMANDING VILLAGE}

Sorting is the process of selecting fruit with good fruit category or worth selling and fruits that rotten or damaged fruit. The sorting process was done with a sitting working position squat on the floor. Changing of sitting position will change with a long time exactly when the muscles feel uncomfortable. Researchers gave interventions in the form of improvement of work stations and william's flexion exercise. Improvement of work station in the form of addition of work table and chair to reduce the occurrence of unnatural work posture. This study was an experimental study, with the same subject design. Period (I) subjects were treated by conventional working conditions. The subject period (II) were treated by intervention in the form of william's flexion exercise and improvement of the work station. Improvement of work station in the form of addition of work table and chair. Between the two period, given washing out period and adaptation. Musculoskeletal complaints were measured by a Nordic Body Map questionnaire on 5 Likert scales, workload by calculating worker's working pulse and work productivity based on output and input ratio. The normality of data was tested with ShapiroWilk, t-paired test to examine differences in meanings of musculoskeletal complaint variables, workload and work productivity.The results of this study showed that william's flexion exercise and work station improvement significantly ( $\mathrm{p}<0.05$ ). Musculoskeletal complaint of $37 \%$, decreased workload by $13 \%$, and $23 \%$ increase in productivity. It can be concluded that giving of william's flexion exercise and improvement of work station could decrease musculoskeletal complaint, workload and increase work productivity at tomato sorter worker. So it suggested to apply to the owners in other to minimize complaints due to the sorting process work.

Keywords: Improvement of work stations, William's Flexion Exercise, Musculoskeletal Complaint, Workload, Productivity

\section{PENDAHULUAN}

Negara Indonesia mayoritas penduduknya menggantungkan hidupnya bekerja pada sector pertanian. Bila dilihat dari sejarah Indonesia pun tidak bisa terlepas dari sector pertanian terutama pada masa kolonial penjajahan Belanda kegiatan pertanian dan perkebunan menjadi penentu tingkat social dan perekonomian seseorang. Data BPS (2002), mengatakan bahwa terdapat 44, $3 \%$ lapangan kerja pada bidang pertanian di Indonesia yang telah tersedia meskipun hanya menyumbang sekitar $17,3 \%$ dari total pendapatan domestik bruto.
Berdasarkan data statistic yang diperoleh oleh BPS Ponorogo (2013) jumlah usaha pertanian di Kabupaten Ponorogo sebanyak 178.908 usaha yang dikelola oleh rumah tangga. Dari sekian banyaknya usaha dibidang pertanian di antaranya adalah penanaman buah tomat. Besarnya kebutuhan pasar tomat membuat banyak para petani di desa Semanding Kecamatan Kauman Kabupaten Ponorogo Jawa Timur memilih untuk melakukan budidaya buah tomat.

Data BPS dan Dirjen Hortikultura RI (2017), menyatakan bahwa produksi tomat provinsi Jawa Timur mencapai 60.706 ton atau mengalami peningkatan sebesar $2,58 \%$ dari tahun sebelumnya. 
Tomat merupakan sayuran buah yang bermacam variasinya mulai dari ukuran buah, bentuk buah, warna buah, tekstur buah, rasa buah, maupun kandungan buahnya yang dapat mempengaruhi mutu buah tersebut.

Pada buah yang akan disortir oleh pekerja adalah buah tomat berjenis gondola/keriting (Lycopersicon validum). Tomat jenis ini mempunyai karakter bentuk buahnya agak lonjong, keras, berkulit tebal sehingga tahan pengangkutan jarak jauh dan daunnya rimbun serta keriting (Ratnasari, 2007).

Setelah proses pemanenan selesai petani melakukan proses penyortiran untuk memilih mutu buah tomat yang baik. Selama ini petani melakukan penyortiran dilakukan di rumah pemilik sawah. Penyortiran dilakukan dengan manual kemampuan manusia. Banyaknya buah tomat yang harus disortir menimbulkan masalah. Sehingga secara ergonomi permasalahan pada proses pemanenan hingga proses penyortiran dapat ditinjau dengan tiga aspek ergonomi (Task, Organization dan Environment).

Dari aspek Task, Penyortiran merupakan proses pemilihan buah dengan kategori buah yang baik atau layak jual dan buah yang busuk atau buah yang rusak. Rata - rata penyortiran membutuhkan waktu hingga 6 jam setiap kali panen. Proses penyortiran dilakukan dengan posisi duduk jongkok terkadang berubah menjadi duduk bersila. Sehingga mengakibatkan timbulnya adanya keluhan musculoskeletal. Berdasarkan hasil studi pendahuluan oleh peneliti pada tahun 2017 didapatkan hasil keluhan muskuloskeletal umumnya dirasakan pada otot bagian betis dan punggung bawah. Pada saat dilakukan pengukuran denyut nadi kerja rata-rata 125 denyut/menit.

Dari aspek organization, Pemanenan buah tomat dilakukan oleh petani dua hari sekali. Penyortiran dilakukan pada pukul 10.00 hingga pukul 16.30 WIB sedangkan waktu istirahat yang diberikan adalah pada pukul $12.00-13.00$
WIB. Pada saat melakukan penyortiran ditemukan juga beberapa kali istirahat curian seperti berdiri, menggerakmenggerakkan tubuh hingga duduk santai meluruskan kaki.

Dari aspek Environment, Proses penyortiran dilakukan di lantai teras garasi rumah pemilik lahan. Pencahayaan lingkungan hanya mengandalkan pencahayaan dari cahaya matahari. Ketika dilakukan pengukuran intensitas cahaya menggunakan Lux meter didapatkan hasil pencahayaan hanya 170 lux. Bila ditinjau dari ilmu ergonomi intensitas cahaya di stasiun kerja terlalu rendah sehingga dapat menimbulkan adanya kelelahan mata.

Bila ditinjau dari permasalahan tersebut maka perlu adanya intervensi ergonomi untuk mengurangi beban kerja dan keluhan musculoskeletal untuk meningkatkan produktivitas petani tersebut. Untuk itu peneliti memberikan intervensi berupa pemberian william's flexion exercise dan perbaikan stasiun kerja pada proses penyortiran. Perbaikan stasiun kerja berupa penambahan meja kerja untuk mengurangi terjadinya sikap kerja yang tidak alamiah. Sedangkan William flexion exercise berupa latihan peregangan yang bertujuan untuk mengurangi tekanan oleh tubuh pada sendi faset (articular weight bearing stress), meregangkan otot dan fasia di daerah dorsolumbal, serta bermanfaat untuk mengoreksi postur tubuh yang salah (Hills, 2006). Dengan intervensi tersebut diharapkan dapat mengurangi beban kerja dan keluhan musculoskeletal pada para pekerja sehingga produktivitas para pekerja maupun petani tersebut dapat meningkat.

\section{METODE PENELITIAN Rancangan Penelitian}

Penelitian ini merupakan penelitian eksperimental ini menggunakan rancangan sama subjek (treatment by subject design).

\section{Populasi dan Sampel}


Populasi target dalam penelitian ini adalah semua pekerja yang melakukan pekerjaan penyortiran buah tomat di Desa Semanding Ponorogo Jawa Timur. Sedangkan populasi terjangkau adalah seluruh pekerjaan penyortiran buah tomat milik Bp Imam sebanyak 15 orang. Sampel untuk penelitian intervensi dengan rancangan sama subjek (Treatment by Subject Design) dihitung berdasarkan rumus Colton (1985) sehingga didapat sampel 12 orang.

\section{Variabel dan Instrumen Penelitian}

1. Perbaikan stasiun kerja berupa pemberian meja kerja dan kursi yang disesuaikan dengan antropomentri subjek untuk proses penyortiran.

2. William flexion exercise merupakan Latihan yang akan dilakukan oleh pekerja sebelum memulai pekerjaannya. Gerakan William flexion exercise terdiri dari 6 macam gerakan. Latihan William flexion dilakukan satu kali pada saat sebelum memulai proses penyortiran selama seminggu durasi latihan yang diperlukan adalah selama 10 menit.

3. Beban Kerja beban yang diterima oleh pekerja baik dari dalam maupun luar tubuh pekerja selama melakukan pekerjaan yang dihitung berdasar kan rerata peningkatan denyut nadi, diukur setiap periode dengan menggunakan metode 10 denyut pada arteri radialis pergelangan tangan kiri dalam posisi berkerja.

4. Keluhan musculoskeletal ialah keluhan yang bersifat subjektif pada otot skeletal dan diukur menggunakan Nordic Body Map dengan 5 skala likert.

5. Produktivitas kerja merupakan perbandingan antara luaran (output) dan masukan (input) per satuan waktu (Manuaba, 2000).

\section{Lokasi dan Waktu Penelitian}

Penelitian dilakukan di Desa Semanding Kecamatan Kauman Kabupaten Ponorogo Jawa Timur. Penelitian dan pengambilan data dilakukan sejak bulan Agustus 2017 Maret 2018.

HASIL PENELITIAN

Karakteristik Subjek Penelitian

Tabel 1 Data Karakteristik Subjek

\begin{tabular}{llll}
\hline Variabel & $\mathrm{n}$ & Rerata & Rentangan \\
\hline Usia (th) & 12 & 40,42 & $30-50$ \\
$\begin{array}{l}\text { Berat Badan } \\
(\mathrm{kg})\end{array}$ & 12 & 60,5 & $50-68$ \\
$\begin{array}{l}\text { Tinggi Badan } \\
(\mathrm{cm})\end{array}$ & 12 & 162,83 & $156-173$ \\
$\begin{array}{l}\text { Indeks Massa } \\
\text { Tubuh(kg/m²) }\end{array}$ & 12 & 22,84 & $20,5-25$ \\
$\begin{array}{l}\text { Pengalaman } \\
\text { Kerja(th) }\end{array}$ & 12 & 13,6 & $4-25$ \\
\hline
\end{tabular}

Berdasarkan Tabel 1 diketahui bahwa rerata umur Subjek adalah 44,4 tahun. Indeks massa tubuh merupakan perbandingan berat badan $(\mathrm{kg})$ dengan kuadrat tinggi badan (m). Sehingga diperoleh rerata indeks massa tubuh Subjek adalah 22,7 ini termasuk dalam kategori normal. Sedangkan pengalaman kerja diketahui subjek memiliki pengalaman kerja minimal 4 tahun.

\section{Kondisi Lingkungan Penelitian}

Tabel 2 Kondisi Lingkungan Kerja

\begin{tabular}{|c|c|c|c|c|c|}
\hline \multirow{2}{*}{ Variabel } & \multicolumn{2}{|c|}{ Periode 1} & \multicolumn{2}{|c|}{ Periode 2} & \multirow[b]{2}{*}{$p$} \\
\hline & Rerata & SB & Rerata & SB & \\
\hline $\begin{array}{l}\text { Suhu } \\
\text { Basah }\left({ }^{\circ} \mathrm{C}\right)\end{array}$ & 22,5 & 0,13 & 22,54 & 0,37 & $0,17^{\mathrm{a}}$ \\
\hline $\begin{array}{l}\text { Suhu } \\
\text { Kering }\left({ }^{\circ} \mathrm{C}\right)\end{array}$ & 27,5 & 0,60 & 27,7 & 0,62 & $0,39^{\mathrm{a}}$ \\
\hline $\begin{array}{l}\text { Kelembaban } \\
\text { Relatif }(\%)\end{array}$ & 63,8 & 0,83 & 64 & 0,70 & $0,70^{\mathrm{b}}$ \\
\hline $\begin{array}{l}\text { Intensitas } \\
\text { Cahaya(Lux) }\end{array}$ & 175,6 & 4,09 & 175,2 & 3,42 & $0,67^{\mathrm{a}}$ \\
\hline
\end{tabular}

Dari Tabel 2 menunjukkan hasil uji kemaknaan diketahui pada variabel kondisi lingkungan tidak memiliki perbedaan yang signifikan pada periode 1 
maupun periode 2. Hal Ini menunjukkan bahwa kedua periode tersebut memiliki karakteristik lingkungan yang sama.

\section{Normalitas Data}

Tabel 3 Uji Normalitas Data Keluhan Muskuloskeletal, Beban Kerja dan Produktivitas Kerja

\begin{tabular}{lcccc}
\hline \multirow{2}{*}{ Variabel } & \multicolumn{2}{c}{ Periode 1} & \multicolumn{2}{c}{ Periode 2} \\
\cline { 2 - 4 } $\begin{array}{l}\text { MSDs } \\
\text { (pre) }\end{array}$ & 30,69 & 0,005 & 31,07 & 0,014 \\
$\begin{array}{l}\text { MSDs } \\
\text { (post) }\end{array}$ & 46,07 & 0,014 & 38,15 & 0,009 \\
$\begin{array}{lcclc}\text { MSDs } \\
\text { (Selisih) }\end{array}$ & 15,38 & 0,001 & 7,07 & 0,029 \\
\hline DNI & 66,00 & 0,033 & 66,25 & 0,64 \\
DNK & 126,91 & 0,018 & 112,41 & 0,107 \\
NK & 60,91 & 0,031 & 46,16 & 0,419 \\
\hline $\begin{array}{l}\text { Produksi } \\
\text { Produkti }\end{array}$ & 128,08 & 0,21 & 128,66 & 0,37 \\
vitas & 0,15 & 0,12 & 0,24 & 0,43 \\
Kerja & & & & \\
\hline
\end{tabular}

Data sebelum kerja (pre) pada Periode 1 menunjukan nilai $p>0,05$. Hal ini berati bahwa data tersebut berdistribusi Normal. Sedangkan data sebelum kerja (Pre) pada Periode 2 dan setelah kerja (post) pada Periode 1 serta 2 menunjukkan nilai $p<0,05$. Hal ini berati bahwa data tersebut berdistribusi tidak normal.

Data denyut nadi istirahat, denyut nadi kerja dan nadi kerja pada Periode 1 menunjukan nilai $p<0,05$. Hal ini berati bahwa data tersebut berdistribusi tidak normal. Sedangkan data denyut nadi istirahat,, denyut nadi kerja dan nadi kerja pada Periode 2 menunjukkan nilai $p>$ 0,05 . Hal ini berati bahwa data tersebut berdistribusi normal.

Data Produksi dan Produktivitas pada Periode 1 dan 2 menunjukkan nilai $p$ $>0,05$. Hal ini berarti bahwa seluruh data produktivitas kerja pada Periode 1 dan 2 berdistribusi normal.

\section{Komparabilitas Data}

Tabel 4 Uji Komparabilitas Data Keluhan Muskuloskeletal, dan Beban Kerja

\begin{tabular}{|c|c|c|c|c|}
\hline & \multicolumn{2}{|c|}{ MSDs } & \multicolumn{2}{|c|}{ Beban kerja } \\
\hline & $p$ & SB & $p$ & SB \\
\hline Periode 1 & 0,29 & 0,86 & 0,546 & 1,62 \\
\hline
\end{tabular}

Periode $2 \longrightarrow 0,86 \quad 2,40$

Dari Tabel 4 diketahui bahwa hasil analisis Uji Wilcoxon untuk kondisi awal (pre) rerata keluhan muskuloskeletal pada Periode 1 maupun Periode 2, diperoleh nilai $p=0,29(p>0,05)$. Hal ini menunjukan bahwa kondisi awal tidak berbeda secara bermakna atau dalam keadaan yang sama. Sedangkan pada kondisi awal (pre) rerata beban kerja pada Periode 1 maupun Periode 2, diperoleh nilai $\mathrm{p}=0,546(p>0,05)$. Hal ini juga menunjukan bahwa kondisi awal tidak berbeda secara bermakna atau dalam keadaan yang sama.

\section{Efek Perlakuan}

Tabel 5 Hasil Uji Efek Perlakuan Menggunakan Uji t-paired dan Wilcoxon

\begin{tabular}{lccc}
\hline Variabel & Periode 1 & Periode 2 & Nilai \\
\cline { 2 - 3 } & Rerata \pm SB & Rerata \pm SB & $P$ \\
\hline MSDs (pre) & $30,69 \pm 0,75$ & $31,07 \pm 0,75$ & 0,29 \\
MSDs (post) & $46,07 \pm 0,75$ & $38,15 \pm 0,68$ & 0,001 \\
MSDs & $15,38 \pm 0,86$ & $7,07 \pm 0,86$ & 0,001 \\
(Selisih) & & & \\
\hline DNI & $66,00 \pm 1,04$ & $66,25 \pm 1,13$ & 0,546 \\
DNK & $126,91 \pm 0,79$ & $112,41 \pm 1,56$ & 0,002 \\
NK & $60,91 \pm 1,62$ & $46,16 \pm 2,40$ & 0,002 \\
\hline Produksi & $128,08 \pm 6,4$ & $128,66 \pm 6,34$ & 0,012 \\
Produktivitas & $0,15 \pm 0,01$ & $0,24 \pm 0,01$ & 0,000 \\
Kerja & & & \\
\hline
\end{tabular}

Berdasarkan tabel 5 dinyatakan bahwa hasil analisis terhadap kondisi akhir (post) dan selisih rerata keluhan muskuloskeletal pada Periode 1 maupun Periode 2, diperoleh nilai $p=0,001$. Hal ini menunjukan bahwa terjadi penurunan keluhan muskuloskeletal yang bermakna pada Periode 1 dan Periode 2.

Keluhan muskuloskeletal terbesar terletak pada pinggang, punggung dan bahu sisi kanan, hal ini disebabkan sikap kerja penyortir yang statis yang cenderung melakukan pekerjaan dengan sikap jongkok disertai dengan adanya gerakan serta adanya gerakan repetitif pada tangan ketika memilih dan mengambil buah sehingga dapat menyebabkan keluhan. Posisi duduk jongkok terlalu lama menyebapkan tidak lancarnya aliran darah pada ekstermitas tubuh pada bagian bawah. 
Keluhan musculoskeletal terjadi disebabkan oleh sikap paksa yang berlangsung lama saat bekerja sehingga terjadi adanya beban pada sistem muskuloskeletal dan efek negatif pada kesehatan. Pendapat lain dari Pheasant (2003) mengatakan bahwa sikap statis dan paksa dapat menghambat aliran darah mengkibatkan tidak terpenuhinya suplai oksigen ke bagian otot. Sehingga terjadi peningkatan asam laktat dan panas tubuh menyebabkan terjadinya nyeri otot pada pekerja. Penelitian yang dilakukan Adiatmika dkk (2007) menyatakan bahwa perbaikan kondisi kerja dengan pendekatan ergonomi total dapat menurunkan keluhan muskuloskeletal sebesar $5,24 \%$ pada perajin pengecatan logam di Kediri Tabanan. Pada Penelitian Surata (2011) bahwa redesain alat dan sistem kerja menurunkan keluhan muskuloskeletal sebesar $56,15 \%$. Latihan William flexion berfungsi untuk mengurangi tekanan pada sendi faset (Articular Weight Bearing Stress) oleh tubuh, merenggangkan otot dan fasia di daerah dorsolumbal, serta dapat mengoreksi postur tubuh yang salah (Hills, 2006).

Denyut nadi kerja dan nadi kerja pada Periode 1 maupun Periode 2, diperoleh nilai $p=0,002$. Hal ini menunjukan bahwa terjadi penurunan beban kerja yang bermakna pada Periode 1 dan Periode 2. Dengan demikian bahwa penurunan yang terjadi semata-mata disebabkan karena adanya intervensi yang diberikan. Sedangkan dari hasil analisis terhadap rerata Produksi diperoleh nilai $p$ $=0,012(p<0,05)$.

Menurunnya beban kerja disebabkan oleh berkurangnya perubahan posisi kerja dari duduk jongkok maupun bersila menjadi duduk dengan kursi dan bantuan meja kerja sehingga mengurangi pembebanan statis dan paksa yang dapat menyebabkan aliran darah terhambat sehingga suplai oksigen ke bagian otot tidak cukup.
Hasil Penelitian mengenai redesain stasiun kerja sejalan denga penelitian Sutarna (2011), yang menyatakan bahwa redesain stasiun kerja berupa penambahan alat kedudukan pelat eser dapat menurunkan beban kerja sebesar 10,4\%. Hasil analisis menunjukkan bahwa sebelum menggunakan alat kedudukan pelat eser (P0) rerata beban kerja mahasiswa sebesar 104,4 denyut/menit sedangkan setelah menggunakan alat kedudukan pelat eser (P1) sebesar 93,5 denyut/menit. Menurut Anderson (2010) yang menyebutkan peregangan aktif dapat mengurangi ketegangan otot dan memperbaiki peredaran darah, sehingga tubuh akan lebih siap dalam bekerja.

Sedangkan hasil analisis produktivitas kerja diperoleh nilai $p=$ $0,000(p<0,05)$. Hal ini menunjukkan bahwa terjadi perbedaan secara signifikan antara Periode 1 dan Periode 2. Dengan demikian bahwa peningkatan yang terjadi semata-mata disebabkan karena adanya perlakuan yang diberikan.

Peningkatan produktivitas kerja pada Periode 2 disebabkan karena adanya latihan William fleksi dan perbaikan stasiun kerja berupa penambahan meja dan kursi kerja sehingga mengakibatkan menurunnya beban kerja serta hasil kerja meningkat dengan waktu kerja yang sama dengan kata lain output lebih besar dan input lebih kecil. Selain itu itu menurunnya keluhan muskuloskeletal dan beban kerja dapat meningkatkan efisiensi waktu kerja dan produktivitas kerja penyortir.

\section{SIMPULAN DAN SARAN Simpulan}

Dari hasil analisis dan pembahasan yang telah dijabarkan sebelumnya, dapat disimpulkan bahwa :

1. Perbaikan Stasiun Kerja dan William flexion exercise menurunkan beban kerja pada pekerja penyortiran buah tomat sebesar $13 \%$.

2. Perbaikan Stasiun Kerja dan William flexion exercise menurunkan keluhan 
musculoskeletal pada pekerja penyortiran buah tomat sebesar 37\%.

3. Perbaikan Stasiun Kerja dan Latihan William flexion exercise meningkatkan Produktivitas kerja pada pekerja penyortiran buah tomat sebesar $23 \%$.

\section{Saran}

Berdasarkan pada simpulan di atas maka dapat disarankan beberapa hal sebagai berikut :

1. Penelitian berikutnya dapat dilakukan dengan memberikan masing-masing intervensi secara terpisah, untuk mengetahui intervensi yang lebih memberikan efek pada keluhan yang ditimbulkan akibat proses kerja menyortir.

2. Perbaikan Stasiun Kerja dan William flexion exercise disarankan untuk dapat diterapkan pada pekerja penyortiran buah tomat dimana saja, agar dapat meminimalkan keluhan yang ditimbulkan akibat proses kerja menyortir.

3. Hasil dari penelitian ini dapat dipakai sebagai acuan bagi penelitian yang sejenis dan bagi peneliti bisa juga dikembangkan ke arah yang lebih mendalam.

\section{DAFTAR PUSTAKA}

Adiatmika, I P G., A. Manuaba., N. Adiputra., D.P. Sutjana. 2007. Perbaikan Kondisi Kerja dengan Pendekatan Ergonomi Total Menurunkan Keluhan Muskuloskeletal dan Kelelahan Serta Meningkatkan Produktivitas dan Penghasilan Perajin Pengecatan Logam di Kediri-Tabanan. Denpasar : Indonesia Journal of Biomedical Science Universitas Udayana

Anderson, B. 2010. Stretching in The Office. Serambi Ilmu Semesta. Jakarta

BPS Kabupaten Ponorogo 2013. Angka Hasil Sementara Sensus Pertanian
2013.

st2013.bps.go.id/st2013esya/booklet/ st3502.pdf. [Cited 2017 May 26]

BPS dan Dirjen Hortikultura RI. 2017. Sub Sektor Hortikultura. http://www.pertanian.go.id/ap_pages /mod/datahorti. [Cited 2017 September 9]

Colton, T. 1985. Statistika Kedokteran. Gajahmada University Press : Yogyakarta.

Hills, E.C. 2006. Mechanical Low Back Pain. Available from http://www.emedicine.com.diakses. Diakses 14 Juli 2017.

Manuaba, A, 2000. Ergonomi Meningkatkan Kinerja dan Perusahaan. Makalah disajikan dalam Simposium dan Pameran Ergonomi Indonesia 2000 di Bandung, 18-19 Nopember 2000.

Ratnasari. 2007. Pra rencana Pabrik Saus Tomat kapasitas 2600 ton per tahun. Available from repository.wima.ac.id/3726/2/BAB\% 201.pdf. Diakses 14 Juli 2017

Pheasant, S. 2003. Ergonomics, Work and Health. London: Macmillan Acsdemic Profesional Ltd

Surata, I W. 2011 "Redesain Alat Pengering Dan Sistem Kerja Meningkatkan Kinerja Petani Dan Mutu Rumput Laut Di Desa Ped Nusa Penida" (disertasi). Denpasar: Program Pascasarjana Universitas Udayana

Sutarna,I.N. 2011. Aplikasi Ergonomi pada Proses Pemotongan Pelat Eser Meningkatkan Kinerja Mahasiswa di Bengkel Teknologi Mekanik Politeknik Negeri Bali. Tesis. Denpasar : Universitas Udayana 